\title{
Gambaran Radiografi Toraks Pasien HIV Dengan Tuberkulosis Paru Berdasarkan Nilai CD4 Di Rumah Sakit Umum Arifin Achmad Provinsi Riau
}

\author{
Jendriella $^{1^{*}}$, Dian Yazmiati², Andreas Makmur², Azizman Saad ${ }^{3}$
}

\begin{abstract}
ABSTRAK
Diagnosis of tuberculosis in HIV-Tuberculosis coinfected patients is difficult. Thorax x-ray is a primary tool to evaluate tuberculosis in HIV. The purpose of this cross-sectional study was to assess and compare various radiological patterns of pulmonary tuberculosis in HIV patients with CD4 counts. This study conducted in Arifin Achmad Hospital Riau province from December 2016-December 2018 with 55 HIV-tuberculosis coinfected patients. WHO guidelines were used for diagnosis of HIV and tuberculosis. $100 \%$ of the patients had sputum positive pulmonary tuberculosis, with higher incidence $(83,6 \%)$ among CD4 less than 200 as compared to CD4 more than $200(16,4 \%)$. Infiltration (32,7\%) followed by normal $(18,2 \%)$, and fibrosis (11\%) seen with CD4 less than 200 . Infiltration $(9,2 \%)$ followed by normal $(3,6 \%)$ and fibrosis $(1,8 \%)$ with CD4 above 200 . Mid and lower zone $(50 \%)$ more commonly seen in CD4 <200. Despite in CD4 >200 upper zones more commonly seen. Most lesions were found in mid zone of lung. There were significant differences in radiological patterns of pulmonary tuberculosis in HIV according to CD4 counts.
\end{abstract}

Keyword : Tuberculosis, Thorax-Xray, CD4

Tuberkulosis paru merupakan masalah kesehatan global saat ini, sehingga keterlambatan diagnosis dan pengobatan dapat berimplikasi pada kesehatan masyarakat secara umum. Manifestasi klinis pada penderita Human Immunodeficiency Virus/ Acquired Immunodeficiency Deficiency Syndrome (HIV/AIDS) dengan kelainan paru sering tidak khas (atipikal). Gambaran radiologi yang berhubungan dengan parameter klinis dan laboratorium terutama derajat imunosupresi yang direfleksikan dengan jumlah CD4 akan sangat membantu dalam upaya penegakan diagnosis kelainan paru pada pasien HIV/AIDS ${ }^{1-3}$.

Karakteristik penderita HIV adalah penurunan sistem imun akibat defisiensi dan gangguan fungsi sel limfosit $\mathrm{T}$, dengan kondisi akhir yang dikenal sebagai AIDS. Pasien dengan HIV/AIDS rentan mengalami berbagai penyakit oportunistik pada paru,

\footnotetext{
* Korespondensi Penulis : ellajendri@gmail.com

1 Program Studi Pendidikan Dokter Spesialis Paru, Fakultas Kedokteran Universitas Riau

2. KJFD Radiologi FK UNRI/ KSM Radiologi RSUD Arifin Achmad Provinsi Riau

3 KJFD Pulmonologi FK UNRI/ KSM Pulmonologi RSUD Arifin Achmad Provinsi Riau
}

terutama infeksi dan keganasan. Kelainan paru oportunisitik pada pasien yang terinfeksi HIV/AIDS dapat dideteksi dengan pemeriksaan foto toraks. Walaupun tidak terdapat gambaran foto toraks yang patognomonis untuk penyakit tertentu, beberapa gambaran radiologi mengarah pada diagnosis yang spesifik ${ }^{3,4}$.

Gambaran kelainan paru oportunistik yang dapat terlihat pada foto toraks sangat bervariasi seperti infiltrat, konsolidasi, nodul, kalsifikasi, kavitas, bayangan kistik, massa, fibrosis, atelektasis, bayangan retikuler, peribronchial cuffing, tramline, gambaran groundglass, emfisema, proses pada pleura, dan pembesaran kelenjar mediastinum maupun perihiler ${ }^{5-6}$. Jumlah Cluster of Differentiation memiliki hubungan yang erat dengan manifestasi klinis pasien HIV. Selain itu, jumlah CD4 merupakan parameter terpenting dalam stratifikasi risiko terjadinya penyakit paru pada pasien dengan HIV/AIDS. Penelitian menunjukkan bahwa semakin rendah jumlah CD4 pada pasien dengan HIV/AIDS, semakin tinggi risiko terjadinya kelainan paru pada penderita tersebut ${ }^{7}$. 
Hampir semua pasien yang terinfeksi HIV mengalami infeksi pernapasan pada satu waktu dalam perjalanan penyakitnya, dengan spektrum klinis yang bervariasi. Penting bagi seorang radiologis untuk selalu mengikuti perubahan pada prevalensi dan epidemiologi penyakit paru pada penderita HIV/ AIDS. Berbagai gambaran radiologi yang berhubungan dengan parameter klinis dan laboratorium (terutama derajat imunosupresi yang direfleksikan dengan jumlah CD4) akan sangat membantu dalam upaya penegakan diagnosis kelainan paru pada pasien HIV/AIDS ${ }^{8-9}$.

Berdasarkan penjabaran di atas serta belum adanya penelitian tentang gambaran radiografi toraks pasien HIV dengan tuberkulosis berdasarkan nilai CD4 di Rumah Sakit Umum Daerah Arifin Achmad Pekanbaru sehingga peneliti tertarik untuk meneliti gambaran radiografi toraks pasien HIV dengan tuberkulosis berdasarkan nilai CD4 di Rumah Sakit Umum Daerah Arifin Achmad Pekanbaru.

\section{METODE}

Jenis penelitian ini adalah penelitian observasional analitik dengan pendekatan Cross sectional untuk mengetahui gambaran radiografi toraks pada penderita HIV dengan tuberkulosis berdasarkan CD4 yang menggunakan data sekunder penderita HIV dengan tuberkulosis yang telah menjalani pemeriksaan radiografi toraks di RSUD Arifin Ahmad Mulai Desember 2016-Desember 2018. Pengambilan sampel dilakukan secara retrospektif di Instalasi Radiologi dan Instalasi Poliklinik VCT RSUD Arifin Achmad Pekanbaru dari bulan Desember 2016-Desember 2018. Subjek penelitian ini diambil dari rekam medis pasien HIV dengan tuberkulosis dan ekspertise foto toraks pasien saat didiagnosis tuberkulosis.

Populasi target pada penelitian ini adalah pasien tuberkulosis dengan HIV yang telah dibuktikan dengan pemeriksaan sputum BTA atau tes molekuler cepat GenExpert. Populasi terjangkau pada pasien ini adalah pasien HIV yang berobat di Poli Voluntary Counseling Testing (VCT) RSUD Arifin Ahmad dan pasien rawat inap di ruang Jasmine RSUD Arifin Achmad baik yang sudah mendapat antiretroviral ataupun belum. Pengambilan sampel dilakukan dengan metode non probability sampling dengan teknik purpossive sampling. Besar sampel penelitian ini adalah 55 orang yang sesuai dengan kriteria inklusi dan eksklusi. Kriteria inklusi pada penelitian ini adalah pasien yang sudah didiagnosis HIV dengan usia lebih dari 18 tahun, telah dilakukan pemeriksaan BTA dan atau tes molekuler cepat GeneXpert, pemeriksaan radiologis toraks serta pemeriksaan CD4. Sementara kriteria eksklusi pada penelitian ini adalah pasien dengan kelainan lain pada paru, seperti tumor paru serta tumor mediastinum dan pasien tuberkulosis dengan HIV yang mendapat pengobatan obat anti tuberkulosis (OAT).

Variabel bebas adalah nilai CD4, sedangkan variabel terikat adalah gambaran foto toraks pasien HIV dengan tuberkulosis (gambaran normal, infiltrat/ konsolidasi, kavitas, efusi pleura, honey comb, limfadenopati hilus/ mediastinum, efusi perikard dan kalsifikasi) dan lokasi lesi (atas, tengah, bawah, normal dan difus). Kemudian dilakukan uji statistik untuk menganalisis perbedaan gambaran radiografi toraks dan lokasi lesi berdasarkan nilai CD4 dengan menggunakan Chi Square Test, dikatakan bermakna jika $\mathrm{p}<0,05$.

\section{HASIL}

Pada penelitian tentang gambaran radiografi toraks pada pasien tuberkulosis dengan HIV berdasarkan jumlah CD4 di Rumah Sakit Umum Daerah Arifin Ahmad Pekanbaru didapatkan 55 orang subjek penelitian yang memenuhi kriteria inklusi untuk dijadikan sampel, dengan jumlah lakilaki sebanyak 42 orang $(76,4 \%)$ dan perempuan sebanyak 13 orang $(23,6 \%)$ dari total sampel 55 orang $(100 \%)$. 
Tabel 1. Distribusi frekuensi karakteristik pasien

\begin{tabular}{|c|c|c|}
\hline Karakteristik demografik & Jumlah & $\%$ \\
\hline Jenis kelamin & & \\
\hline Laki-laki & 42 & $76,4 \%$ \\
\hline Perempuan & 13 & $23,6 \%$ \\
\hline Kelompok Umur & & \\
\hline$<30$ tahun & 14 & $25,5 \%$ \\
\hline 31-40 tahun & 22 & $40 \%$ \\
\hline$>41$ tahun & 19 & $34,5 \%$ \\
\hline Karakteristik Medik & Jumlah & $\%$ \\
\hline Kadar CD4 & & \\
\hline$=200$ & 46 & 83,6 \\
\hline$>200$ & 9 & 16,4 \\
\hline Pengobatan HIV & & \\
\hline Dalam ARV & 39 & 70,9 \\
\hline Belum ARV & 16 & 29,1 \\
\hline Pengobatan OAT & & \\
\hline Belum Pernah & 44 & $80 \%$ \\
\hline Putus & 11 & $20 \%$ \\
\hline Relaps & - & - \\
\hline
\end{tabular}

Berdasarkan tabel 1 di atas, didapatkan mayoritas subjek penelitian memiliki usia dengan rentang 31-40 tahun sebanyak 22 orang (40\%). Sedangkan untuk subjek paling sedikit sebaran data menunjukan angka yang sama pada usia $<30$ tahun sebanyak 14 orang $(25,5 \%)$. Pada subjek penelitian memiliki kadar CD4 $<200$ sebanyak 46 orang $(83,6 \%)$ dan kadar CD4 >200 sebanyak 9 orang $(16,4 \%)$. Pengobatan HIV dalam ARV sebanyak 39 orang
(70,9\%) dan belum ARV sebanyak 16 orang $(29,1$ $\%)$. Pasien dengan pengobatan OAT yang belum pernah mendapatkan terapi OAT 44 orang $(80 \%)$, pasien dengan putus obat 11 orang $(20 \%)$ serta tidak terdapat pasien yang relaps.

Berikut adalah gambaran Frekuensi pemeriksaan sputum pada pasien tuberkulosis dengan HIV di Rumah Sakit Umum Daerah Arifin Ahmad Pekanbaru.

Tabel 2. Gambaran distribusi subjek menurut pemeriksaan laboratorium tuberkulosis positif

\begin{tabular}{lll}
\hline Pemeriksaan & Jumlah & $\%$ \\
\hline BTA & 40 & 72,7 \\
GenExpert & 15 & 27,3 \\
\hline & 55 & 100 \\
\hline
\end{tabular}

Berdasarkan tabel 2. didapatkan bahwa subjek penelitian dengan pemeriksaan sputum BTA dengan jumlah 40 orang $(72,7 \%)$ dan pemeriksaan sputum
Gen Expert 15 orang $(27,3 \%)$ dari total sampel penelitian 55 orang. 


\section{Gambaran radiologis tuberkulosis}

Tabel 3. Sebaran subjek menurut gambaran radiografi toraks

\begin{tabular}{lll}
\hline Kelainan Paru & Nilai CD4 & Jumlah (\%) \\
\hline Infiltrat/ konsolidasi & $=200$ & $18(32,7 \%)$ \\
& $>200$ & $5(9,2 \%)$ \\
Normal & $=200$ & $10(18,2 \%)$ \\
& $>200$ & $2(3,6 \%)$ \\
Fibrosis & $=200$ & $6(11 \%)$ \\
& $>200$ & $1(1,8 \%)$ \\
& $=200$ & $3(5,4 \%)$ \\
Kavitas & $>200$ & $1(1,8 \%)$ \\
& $=200$ & $2(3,6 \%)$ \\
Limfadenopati hilus & $>200$ & $0(0 \%)$ \\
& $=200$ & $3(5,4 \%)$ \\
Efusi Pleura & $>200$ & $0(0 \%)$ \\
& $=200$ & $4(7,3 \%)$ \\
Milier & & $0(0 \%)$ \\
& & $55(100 \%)$ \\
\hline
\end{tabular}

Tabel 3. tersebut menunjukkan variasi gambaran radiografi toraks pada pasien HIV dengan tuberkulosis, terlihat infiltrat merupakan gambaran radiografi toraks yang tersering terdapat pada subjek penelitian yaitu sebanyak 23 orang. Selanjutnya yang terbanyak adalah gambaran radiografi toraks normal pada 12 orang dan pada fibrosis yaitu pada 7 orang. Infiltrat/ konsolidasi paling banyak terdapat pada kelompok CD4 $\leq 200$ sel/iL sebanyak 18 orang, sedangkan pada CD4 $>200$ sel/ì 5 orang. Gambaran normal terdapat pada kelompok CD4 $\leq$ 200 sel/iL sebanyak 10 orang, sedangkan pada CD4 $>200 \mathrm{sel} / \mathrm{iL} 2$ orang. Fibrosis terdapat pada kelompok CD4 $\leq 200 \mathrm{sel} / \mathrm{iL}$ sebanyak 6 orang, sedangkan pada CD4 $>200$ sel/ì 1 orang. Kavitas terdapat pada kelompok CD4 $\leq 200$ sel/iL sebanyak 3 orang, sedangkan pada CD $4>200$ sel/iL 1 orang. Limfadenopati hilus terdapat pada kelompok CD4 $\leq$ $200 \mathrm{sel} / \mathrm{iL}$ sebanyak 2 orang, dan tidak terdapat gambaran tersebut pada CD4 $>200 \mathrm{sel} / \mathrm{iL}$. Efusi pleura terdapat pada kelompok CD4 d" $200 \mathrm{sel} / \mathrm{iL}$ sebanyak 3 orang, sedangkan pada CD4 $>200 \mathrm{sel} /$ ì tidak ditemukan. Milier terdapat pada kelompok CD4 $\leq 200$ sel/îL sebanyak 4 orang, sedangkan pada CD4 $>200$ sel/ì tidak ditemukan. Uji statistik menggunakan Chi Square menunjukkan terdapat perbedaan yang bermakna gambaran radiografis toraks berdasarkan nilai CD4 $(p=0,03)$. Perbandingan dilakukan analisis statistik dengan uji dengan nilai $\mathrm{p}=0,03(<0,05)$. 


\section{Gambaran radiografi berdasarkan lokasi}

Tabel 4 Distribusi Lokasi pembagian paru terhadap CD4

\begin{tabular}{cccccccc}
\hline \multirow{2}{*}{ Nilai CD4 } & \multicolumn{5}{c}{ Lokasi pembagian Paru } & \multirow{2}{*}{ Total } \\
\cline { 3 - 6 } & & Atas & Tengah & Bawah & Normal & Diffuse & \\
\hline \multirow{2}{*}{ CD4 } & $<200$ & 9 & 17 & 6 & 10 & 4 & 46 \\
\multirow{2}{*}{ Total } & $>200$ & 7 & 0 & 0 & 2 & 0 & 9 \\
& & 16 & 17 & 6 & 12 & 4 & 55 \\
\hline
\end{tabular}

Tabel 4 diatas menunjukkan variasi lokasi pembagian paru, terlihat pada CD $4<200$ didapatkan lokasi pembagian paru yang terbanyak gambaran tengah yaitu sebanyak 17 orang subjek, normal terdapat 10 orang serta bagian atas sebanyak 9 orang. Sedangkan pada CD4 $>200$ menunjukkan yang terbanyak pada lapangan atas sebanyak 7 orang dan diikuti dengan gambaran normal sebanyak 2 orang. Perbandingan dilakukan analisis statistik dengan uji Chi Square dengan nilai $\mathrm{p}=0,03(<0,05)$.

\section{PEMBAHASAN}

Pada pembahasan ini akan diuraikan tentang gambaran radiografi toraks berdasarkan jumlah CD4. Pada pasien dengan derajat imunosupresi yang berat, resiko terkena tuberkulosis tinggi tetapi sangat sulit untuk membedakan tuberkulosis dengan penyakit lainnya. Pasien HIV- tuberkulosis dapat memiliki gejala tuberkulosis klasik, tapi banyak yang hanya memiliki sedikit gejala tuberkulosis, terdapat sekitar seperlima pasien HIV - tuberkulosis dengan gambaran radiografi toraks yang normal. Ini dikenal dengan tuberkulosis subklinik yang tidak terdeteksi sebagai tuberkulosis sehingga mengalami keterlambatan diagnosis dan terapi.

Pada penelitian ini didapatkan 55 subjek penelitian, dari subjek penelitian yang ada terdapat 42 orang laki-laki dan 13 orang perempuan. Subjek terbanyak memiliki nilai CD4 $\leq 200 \mathrm{sel} / \mathrm{i} \mathrm{L}$ sebanyak 46 orang serta CD $4>200$ sel/iL sebanyak 9 orang. Pada penelitian ini yang terbanyak CD $4 \leq 200 \mathrm{sel} /$ iL, dikatakan di banyak jurnal dapat memberi gambaran radiografi toraks yang berbeda-beda. Semua subyek penelitian memiliki hasil BTA positif baik secara pemeriksaan BTA sputum dan pemeriksaan genExpert.
Subyek penelitian yang sudah mendapat terapi ARV sebanyak 39 orang $(70,9 \%)$ dan 16 orang $(29,1 \%)$ yang belum mendapat terapi ARV saat didiagnosis tuberkulosis. Subjek HIV - tuberkulosis dengan nilai CD4 $\leq 200 \mathrm{sel} / \mu \mathrm{L}$ lebih sering infiltrat/ konsolidasi. Kisembo et al yang mengadakan penelitian di Kampala, Uganda dari bulan September 2007 sampai dengan bulan Juli 2008 mengatakan sebaliknya, CD4 $\leq 200 \mathrm{sel} / \mathrm{iL}$ lebih sering terdapat limfadenopati hilus/ mediastinum dibandingkan gambaran radiografi toraks yang lain yaitu $30 \%$ dari 214 orang subjek penelitian tersebut. Kisembo melakukan penelitian dengan membandingkan dua kelompok besar yaitu HIV seronegatif-tuberkulosis dengan HIV seropositif tuberkulosis ${ }^{16}$.

Infiltrat lebih sering terjadi di lapangan tengah paru pada pasien dengan imunitas rendah dikarenakan oleh anatomi dari lapangan tengah memudahkan untuk terjadinya infiltrat disana sebagai akibat inflamasi atau edema. Diameter yang kecil dari bronkus lobaris menyebabkan drainase yang buruk. Distribusi dari droplet yang diinhalasi ditentukan oleh pola ventilasi dan volum dari tiap lobus paru, sehingga implantasi yang sering di lobus tengah dan lobus bawah, walaupun lobus manapun dapat terkena. Sedangkan pada tuberkulosis post primer predileksinya di lapangan atas paru dikarenakan kombinasi dan berbagai faktor antara lain tekanan oksigen yang tinggi didaerah tersebut dan terganggunya aliran kelenjar getah bening di daerah tersebut. Gambaran klinis tuberkulosis pada pasien HIV tergantung pada derajat ringannya imunosupresinya. Pasien dengan imunosupresi yang masih baik maka gejalanya serupa dengan pasien non-HIV dan hanya mengenai paru. Sedangkan pasien HIV lanjut (CD4 $<200 \mathrm{sel} / \mathrm{iL})$ tuberkulosis pulmoner sering disertai dengan ekstra paru ${ }^{16}$. 
Sedangkan untuk gambaran kavitas, Kisembo et al mengatakan jarang terdapat pada CD4 $\leq 50$ sel/iL, tetapi pada penelitian ini terdapat kavitas masing-masing pada 4 orang dari 55 orang subjek HIV - tuberkulosis dengan nilai CD4 $\leq 200 \mathrm{sel} / \mathrm{iL}$. Variasi gambaran radiografi toraks pasien HIV dengan tuberkulosis bermacam-macam, dari Kisembo et al dikatakan terbanyak adalah infiltrat/ konsolidasi diikuti oleh limfadenopati intra torakal. Hal ini sama dengan yang diperoleh dari hasil penelitian didapatkan infiltrat merupakan gambaran yang paling banyak terdapat dari subyek penelitian, namun diikuti oleh gambaran normal. Sedangkan gambaran normal menduduki tempat kelima pada penelitian Kisembo et al setelah kavitas dan efusi pleura. Menurut Agizew et al yang mengadakan penelitian di Atlanta, Georgia dari bulan November 2004 sampai dengan bulan Juni 2006, infiltrat juga terbanyak pada penelitian mereka yaitu $42 \%$ dari total 156 subyek penelitian, fibrosis $35 \%$, nodul $27 \%$, kelainan pada pleura $15 \%$. Penelitian ini melihat gambaran radiografi toraks pasien HIV tuberkulosis yang mendapat terapi isoniazid ${ }^{16,19}$.

Menurut penelitian Nwonwu et al di Nigeria dari bulan 2004 sampai dengan bulan maret 2006 terdapat gambaran radiografi toraks yang sering ditemui adalah kavitas sebanyak 64,1\%\% dari 117 subjek diikuti oleh infiltrat/ konsolidasi sebanyak $44,4 \%$ dan efusi pleura sebanyak $4,3 \%$. Nwonwu et al sendiri membandingkan pasien tuberkulosis pada kelompok HIV positif dan HIV negatif. Sedangkan dari penelitian ini didapatkan hasil gambaran radiografi toraks yang paling sering ditemui adalah infiltrat/ konsolidasi sebanyak 23 orang dari total 55 subjek, diikuti dengan gambaran toraks normal pada 12 orang dan pada 2 orang dengan gambaran limfadenopati dan mediastinum ${ }^{17}$.

Rabkin et al mengatakan gambaran radiografi toraks yang tipikal untuk tuberkulosis seperti infiltrat di lapangan atas, infiltrat fibronoduler dan kavitas seringnya terlihat pada pasien dengan CD4 yang relatif masih tinggi. Namun pada pasien dengan penyakit yang telah lanjut tidak ada gambaran radiografi toraks yang tipikal, infiltrat lebih sering terdapat di lapangan tengah dan lapangan bawah paru, adenopati intra torakal, pola milier dan retikulonodular serta keterlibatan pleura dan parakardial. Sehingga dapat dikatakan pada pasien dengan HIV lanjut dan tuberkulosis gambaran radiografi toraksnya tidak khas. Hal ini sangat penting untuk dipahami sehingga pasien-pasien HIV dengan tuberkulosis dapat diketahui dan diobati. Sesuai pada penelitian ini ditemukan gambaran radiologis infiltrat pada CD4 $<200$ sebanyak 17 orang dan terletak pada lokasi lapangan tengah dan bawah terdapat sebanyak masing-masing 11 orang dan 3 orang. Sementara pada pasien dengan CD $4>200$ ditemukan Infiltrat lapang atas dan kavitas ditemukan sebanyak 7 orang dari jumlah pasien 9 orang yang merupakan gambaran radiologis tipikal pada tuberkulosis ${ }^{18}$.

Subjek penelitian sebanyak 12 orang $(21 \%)$ dari total 55 subyek penelitian HIV- tuberkulosis dengan nilai $\mathrm{CD} 4 \leq 200 \mathrm{sel} / \mathrm{iL}$ serta CD4 $>200 \mathrm{sel} / \mathrm{iL}$ memiliki gambaran radiografi toraks normal. Hal ini sesuai dengan penelitian oleh Chamie et al yang melakukan penelitian di California yang meneliti pasien dengan HIV positif dan tuberkulosis - HIV negatif, pada 183 orang (21\%) dari total 873 subyek penelitiannya memiliki gambaran toraks yang normal pada kelompok dengan CD4 $\leq 50 \mathrm{sel} / \mathrm{iL}$. Karena banyak variasi gambaran radiografi toraks tidak sensitif untuk diagnosis CD4 yang didapat, sehingga dikatakan bahwa radiografi toraks tidak sensitif untuk diagnosis HIV dengan tuberkulosis terutama pada HIV stadium lanjut, bahkan pada subyek dengan nilai CD4 $\geq 350 \mathrm{sel} / \mathrm{iL}$. Penelitian-penelitian terdahulu mendapatkan pasien HIV- Tuberkulosis dengan CD4 $\leq 50 \mathrm{sel} / \mathrm{iL}$ sekitar $2 \%-22 \%{ }^{22}$.

Infiltrat paling sering terdapat di lapangan tengah yaitu sebanyak 11 orang $(20 \%)$ dari 55 subyek HIV - tuberkulosis. Hal ini sesuai dengan penelitian oleh Padyana $\mathrm{M}$ et al di India yang melakukan penelitian pada HIV positif, yang mengatakan infiltrat pada pasien tuberkulosis dengan HIV dapat terjadi di kedua lapangan, dengan lebih sering pada lapangan tengah dan lapangan bawah paru yaitu sebanyak $68,5 \%$ dari 200 subyek penelitiannya yang dikerjakan dari bulan Agustus 2009 sampai bulan Juli 2011. Menurut Kisembo et al, infiltrat difus lebih sering terdapat pada pasien dengan non-tuberkulosis HIV dibandingkan dengan pasien tuberkulosis-HIV ${ }^{16}$.

Pasien dengan nilai CD4 dibawah $200 \mathrm{sel} / \mathrm{ì} \mathrm{L}$ berupa infiltrat tanpa kavitas dan konsolidasi yang dominan. Keterlibatan paru tidak khas, dapat difus, 
infiltrat di lapangan tengah dan lapangan bawah paru akan lebih sering ditemukan dibanding gambaran khas tuberkulosis berupa infiltrat di lapangan atas paru. Perlunya kecurigaan yang tinggi akan infeksi tuberkulosis pada pasien HIV. Pada pasien dengan imunosupresi ringan, gambaran radiografi toraksnya biasanya berupa infiltrat di lapangan atas dan atau kedua paru, kavitas, fibrosis dan volum paru yang mengecil (atelektasis). Gambaran klinis seperti tuberkulosis paru post primer dan sputum BTA biasanya positif. Pada pasien dengan immunosupresi yang berat, gambaran radiografi tidak khas seperti tuberkulosis primer. Sputum BTA biasanya negatif dan gambaran radiografinya dapat berupa infiltrat interstitial, khususnya di lapangan bawah paru dan tidak ada gambaran kavitas dan fibrosis.

Pada penelitian ini, infiltrat terdapat lebih banyak pada kelompok CD4 $\leq 200$ sel/ìL yaitu sebanyak 17 orang (31\%), sedangkan pada kelompok CD4 $>200$ sel/ì sebanyak 5 orang (10\%). Dari penelitian yang dilakukan dr. Eka di Rumah Sakit Umum Pusat Dr. Kariadi Semarang didapatkan juga terbanyak pasien HIV yang menderita tuberkulosis dengan nilai CD4 $\leq 50$ sel/î yaitu sebanyak 16 orang $53,3 \%$ dari total 30 subyek penelitiannya. Lakilaki juga merupakan jenis kelamin yang terbanyak menderita HIV - tuberkulosis dibandingkan perempuan yaitu 19 orang (63,3\%). Didapatkan perbedaan yang bermakna antara gambaran konsolidasi, limfadenopati hilus/mediastinum dan efusi pleura dengan jumlah CD4 tetapi tidak terdapat perbedaan yang bermakna antara kavitas dengan jumlah CD4, sehingga dapat diambil kesimpulan bahwa gambaran radiografi toraks dapat menentukan jumlah CD4 pada pasien tersebut. Diperlukannya pemeriksaan lanjutan berupa CT Scan toraks untuk melihat kelainan pada pasien HIV dengan tuberkulosis terutama pada pasien yang didapatkan gambaran normal pada pemeriksaan radiografi toraknya. Karena dari beberapa kepustakaan mengatakan gambaran radiografi toraks normal yang didapatkan dari pemeriksaan radiografi toraks biasa jika dilanjutkan dengan pemeriksaan CT Scan toraks maka akan didapatkan kelainan dari parenkim paru tersebut, sehingga pasien HIV - tuberkulosis dapat segera di diagnosis dan mendapatkan terapi yang tepat.

\section{SIMPULAN}

Gambaran radiografi toraks terbanyak pada pasien HIV dengan tuberkulosis adalah gambaran infiltrat sebanyak 22 orang dengan nilai CD4 $\leq 200$ sel/iL sebanyak 18 orang $(32,7 \%)$ serta CD4 $>200$ sel/ì sebanyak 5 orang $(9,2 \%$,). Gambaran radiografi berdasarkan lokasi pembagian paru pada CD4<200 terbanyak pada gambaran tengah dan bawah yaitu dengan total 23 orang (42\%), sedangkan pada CD4 $>200$ terbanyak pada lokasi paru bagian atas yaitu sebanyak 7 orang (13\%). Terdapat perbedaan yang bermakna gambaran radiografi toraks dan lokasi lesi berdasarkan nilai CD4.

\section{DAFTAR PUSTAKA}

1. Daley CL, Gotway MB, Jasmer RM. Radiographic manifestations of tuberculosis : a primer for clinicians. San Fransisco : Francus J. Curry National Tuberculosis Center: August 2003.

2. Ngowi BJ, M FInanga SG, Bruun JN and Morkve O. Pulmonary tuberculosis among people living with HIV/AIDS attending care and treatment in rural northern Tanzania. BMC : Public Health 2008, 8:341.

3. Fauci AS, Lane HC. Human Immunodeficiency Virus Disease: AIDS and related disorders. In: Fauci AS, Braunwald, Kasper DL, Hauser SL, Longo DL, Jameson JL, et al., ed. Harrison's Principles of Internal Medicine. 17 $7^{\text {th }}$ ed. New York:McGrawHill Medical; 2008.

4. Fishman AP, Elias JA, Fishman JA, Grippi MA, Senior RM, Pack AI. Fisman's pulmonary diseases and disorders. $4^{\text {th }}$ edition. Volume two. New York: McGraw-Hill; 2008.

5. Shah RM, Kaji AV, Ostrum BJ, Friedman AC. Interpretation of chest radiographs in AIDS patients: usefullness of CD4 lymphocyte counts. RadioGraphics 1997; 17:47-58.4.

6. Padley SPG, Rubens MB. Pulmonary infections. In: Sutton D, ed. Textbook ofradiology and imaging. $7^{\text {th }}$ ed. Philadelphia: Churchill Livingstone; 2003. 
7. Aviram G, Fishman JE, Boiselle PM. Thoracic manifestations of AIDS: infectious lung diseases in AIDS. Applied Radiology. 2003 [cited 2009 Des 26]; 32(8). Available from: http://www.medscape.com/viewarticle/ 4610463 3 .

8. Aviram G, Fishman JE, Boiselle PM. Thoracic manifestations of AIDS: noninfectious lung diseases in AIDS. Applied Radiology. 2003 [cited 2009 Des 26]; 32(8). Available from: http://www.medscape.com/vieawarticle/ 461046_4/.

9. Gold JA, Rom WN, Harkin TJ. Significance of abnormal chest radiograph findings in patients with HIV-1 infection without respiratory symptoms. Chest 2002; 121(5):14727.

10. Schneider RF, Hansen NI, Rosen MJ, Kvale PA, Fulkerson WJ Jr, Goodman P,et al. Lack of usefulness of radiographic screening for pulmonary disease in asymptomatic HIVinfected adults. Pulmonary complication of HIV infection study group. Arch Intern Med. 1996;156(2): 191-5.

11.Tjandra YA,Subuh M. Petunjuk tekhnis tatalaksana klinis ko-infeksi TB-HIV. Jakarta : Kementrian Kesehatan RI 2012; 16-150.

12. Yayasan Spiritia. Statistik kasus HIV/AIDS di Indonesia dilapor s.d Desember 2009. Sumber Ditjen PPM \& PL Departemen Kesehatan Republik Indonesia. 2009 [cited 2010 Feb 2]. Available from http://www.spritia.or.id

13. Hull MW, Phillips P, Montaner JSG. Changing global epidemiology of pulmonary manifestations of HIV/AIDS. Chest 2008; 134:1287-98.

14. Brecher CW, Aviram G, Boiselle PM. CT and radiography of bacterial respiratory infections in AIDS patiens. AJR. 2003; 180:1203-9.

15.Barber S, Adioetomo SM, Ahsan A, Setyonaluri D. Aspek ekonomi tembakau di indonesia. [cited 2010 Apr 12] Available from : http://www.tobaccofreeunion.org/assets/ TechnicalResources/EconomicReports/ TobaccoTaxesInIndonesia-ID.pdf

16. Kisembo HN, Boon SD, Davis JL, Okello R, Worodria W, Cattamanchi A et la. Chest radiographic dinding of pulmonary tuberkulosis Ni severely immunocompromised patients Alt human immunodeficiency virus. The British Journal of Radiology; June 2012. P. 130-40

17. Nwonwu EU, Oyibu PG, Imo AOC, Obion CN, Uneke CJ. Radiological features of pulmonary tuberkulosis Ni HIV-positive Ana HIV negatif adult patients in South- Eastern Nigeria. African jurnal of Respiratory medicine. March 2008. P.204

18. Rabkin, El-Sadr, Abrams. Diagnosis ana management of HIV-related tuberkulosis. The Columbia Clinical Manual; September 2004.

19. Agiziew T, Bachhuber A, Nyirenda S, Makwaruzi VZSAM, Tedla Z, Tallaksen RJ et la. Association of chest radiographic abnormalitas Alt tuberkulosis disease in assymptomatic HIVinfected adults. The internasional Journal of Tuberculosis Ana Lung Disease. 2010; 14(3):32431.

20.Padyana M, Bhat RV, Dinesha M, Nawaz A. Hiv- Tuberculosis ; a Study chest x-ray patterns in relation do CD4 count. N Am J Med Sci. 2012; $4(5) ; 221-5$

21. Sastroasmoro S, Ismael S. Dasar-dasar metodologi penelitian klinis. Edisi ke 3. Sagung Seto. 2010. Hal. 302-30.

22. Chamie G, Luetkemenyer A, Walusimbi-Nanteza M, Okwera A, Whallen C, Mugerwa RD et la. Signifikan variation in presentation of pulmonary tuberkulosis Cross a High resolution of CD4 strata. Int J Tubere Lung Dis. 2010 October ;14(10):1295-1302. 